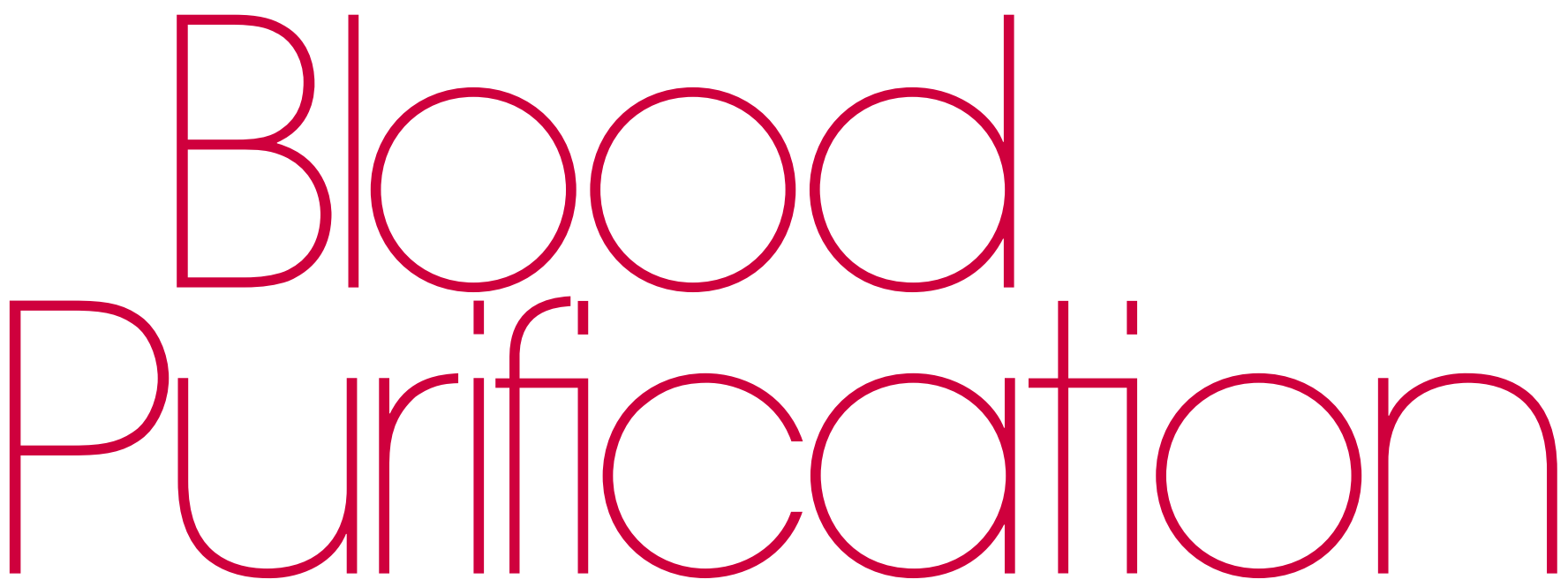

\begin{tabular}{ll}
\hline & $\begin{array}{l}\text { International Society } \\
\text { of Blood Purification (ISBP) }\end{array}$ \\
\hline JSBPCC & $\begin{array}{l}\text { Japan Society for } \\
\text { Blood Purification in Critical Care } \\
\text { (JSBPCC) }\end{array}$ \\
\hline
\end{tabular}

\title{
Japanese Society for
}

III) Hemodiafiltration (JS-HDF)

血㳸凈化 Chinese Society of Blood

血液净化 Purification Administration (CSBPA) 


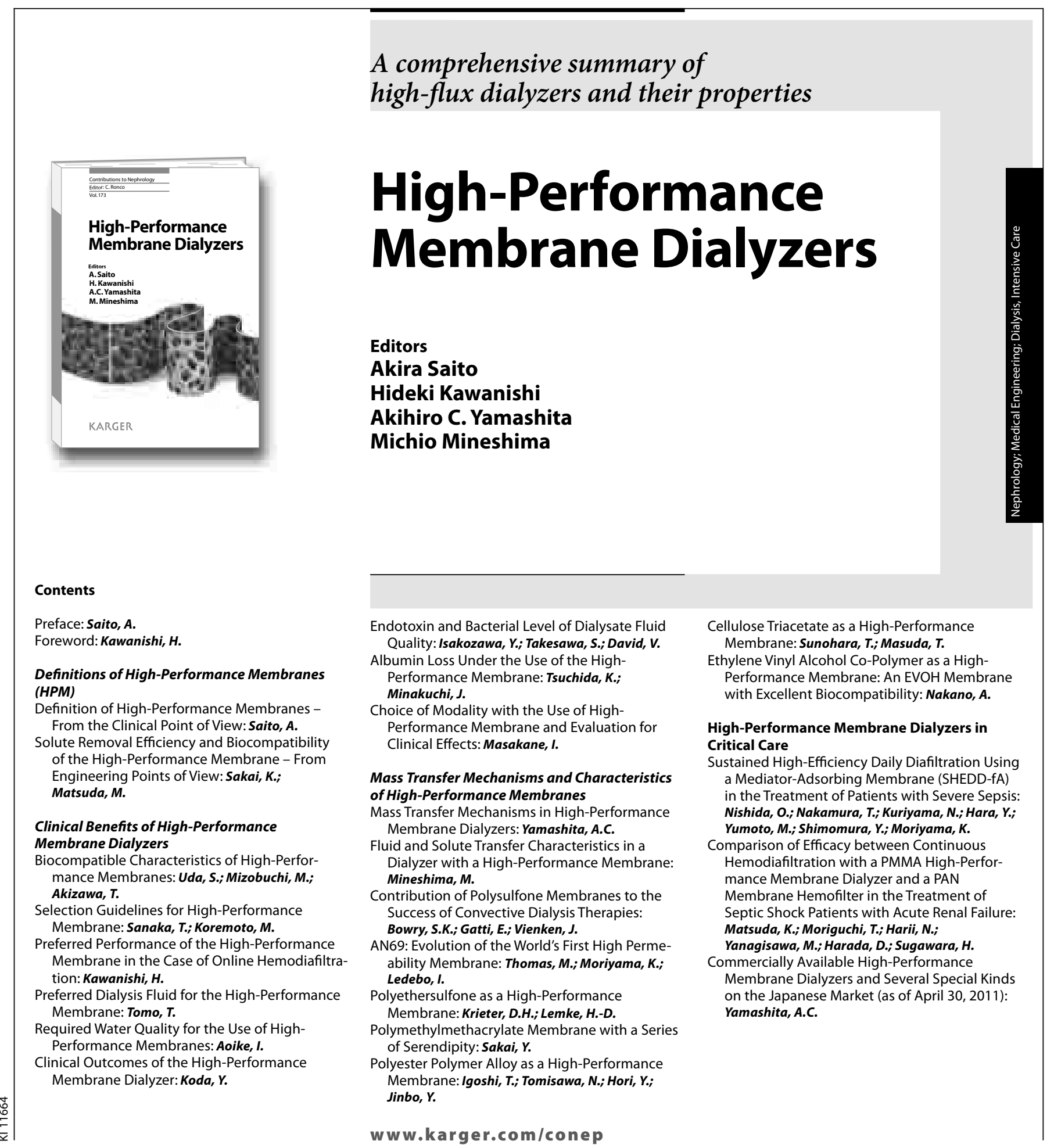

Contributions to Nephrology, Vol. 173

Series Editor: Ronco, C. (Vicenza)

ISSN 0302-5144 / e-ISSN 1662-2782

High-Performance Membrane Dialyzers Editors: Saito, A. (Isehara); Kawanishi, H. (Hiroshima), Yamashita, A.C. (Fujusawa); Mineshima, M. (Tokyo) $X+200$ p., 61 fig., 7 in color, 21 tab., hard cover, 2011 CHF 198.- / EUR 165.- / USD 233.00

Prices subject to change

EUR price for Germany, USD price for USA only

ISBN 978-3-8055-9812-5

e-ISBN 978-3-8055-9813-2 $\rightarrow$

Postage and handling free with prepayment

E Payment:

Please charge to my credit card

- $\square$ American Express $\square$ Diners

ᄂ $\square$ MasterCard $\square$ Visa

- Card No.

๑

ס

CVV/CVC

( 3 digits in the signature field on the back of Visa and MasterCard)

$\square$ Check enclosed $\square$ Please bill me

Orders may be placed with any bookshop, subscription agency, directly with the publisher or through a Karger distributo
Fax: +41 613061234

S. Karger AG, P.O. Box, CH-4009 Basel (Switzerland) E-Mail orders@karger.ch, www.karger.com

Name/Address: 
Official Journal of the International Society of Blood Purification (ISBP)

Official Journal of the Japan Society for Blood Purification in Critical Care (JSBPCC)

Official Journal of the Japanese Society of Hemodiafiltration (JS-HDF)

Official Journal of the Chinese Society of Blood Purification Administration (CSBPA)

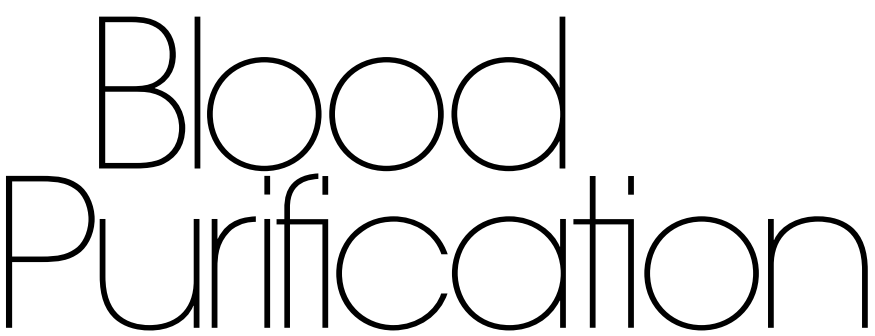

Founded 1983 by K. Schaefer;

continued by L.W. Henderson (1989-2000), K.M.L. Leunissen (2001-2007)

International Society of Blood Purification

Editorial Representative

G. Lonnemann, Hannover

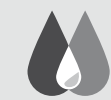

\section{JSBPCC}

Japan Society for Blood Purification in Critical Care

Editorial Representatives

S. Oda, Chiba

K. Matsuda, Yamanashi

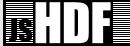

Japanese Society of Hemodiafiltration Editorial Representative

A. Yamashita, Fujisawa

血液凈化

Chinese Society of

Blood Purification Administration

Editorial Representative

M. Wang, Beijing

\section{Editor-in-Chief}

C. Ronco, Vicenza

\section{Assistant Editor}

S. Chiaramonte, Vicenza

\section{Associate Editors}

P. Aljama, Cordoba

R. Bellomo, Melbourne, Vic.

D.N. Cruz, Vicenza

A. Davenport, London

W.L. Henrich, San Antonio, Tex.

H. Kawanishi, Hiroshima

J.A. Kellum, Pittsburgh, Pa.
N.W. Levin, New York, N.Y.

R.L. Mehta, San Diego, Calif.

V. Panichi, Lido di Camaiore

P.M. Palevsky, Pittsburgh, Pa.

Z. Ricci, Rome

M.C. Riella, Parana

P. Stenvinkel, Stockholm

\section{Editorial Board}

T. Akiba, Tokyo

R. Amerling, New York, N.Y.

A. Al-Khader, Riyad

W. Arkouche, Lyon

S. Ash, West Lafayette, Ind.

B.J.-M. Canaud, Montpellier

C. Chazot, Tassin

A.K. Cheung, Salt Lake City, Utah

W. Clark, Indianapolis, Ind.
J.T. Daugirdas, Chicago, Ill.

S. Di Giulio, Rome

D. Falkenhagen, Krems

K. Farrington, Stevenage

L. Garred, Thunder Bay, Ont.

N. Gibney, Edmonton, Alta.

T. Goodship, Newcastle upon Tyne

M. Haapio, Helsinki

O. Heimbürger, Stockholm

(Continued on next page)

Printed in Switzerland on acid-free and non-aging paper (ISO 9706) by Reinhardt Druck, Basel
Appears every 6 week: 2 volumes per year (8 issues) 
(Continued)

\section{Editorial Board}

N. Hoenich, Newcastle upon Tyne W.H. Hörl, Vienna

C. Holmes, McGaw Park, Ill.

A.A. House, London, Ont.

K.-Y. Hung, Taipei

S.H. Jacobson, Stockholm

S. Jorstad, Trondheim

A.A. Kaplan, Farmington, Conn.

M. Ketteler, Coburg

P. Kotanko, New York, N.Y.

R. Krediet, Amsterdam

K. Kurokawa, Tokyo

M. Leblanc, Montréal, Que.

J.K. Leypoldt, Salt Lake City, Utah

B. Lindholm, Stockholm

F. Locatelli, Lecco

G.M. London, Fleury-Mérogis

D. Lumlertgul, Bangkok

M. Lysaght, Providence, R.I.

K. Maeda, Nagoya

P. Messa, Milan

J.M. Morales, Madrid

R. Pecoits-Filho, Curitiba

H. Rabb, Baltimore, Md.

B. Robinson, Ann Arbor, Mich.
A. Santoro, Bologna

I. Sauer, Berlin

R. Schindler, Berlin

S.J. Schwab, Memphis, Tenn.

S. Shaldon, Monaco

S. Silva, Porto

P. ter Wee, Amsterdam

Y. Takemoto, Osaka

V. Tesař, Prague

C. Tetta, Bad Homburg

C. Tieleman, Brussels

N. Topley, Cardiff

L. Turmel-Rodrigues, Tours

S. Uchino, Tokyo

J.-L. Vanherweghem, Brussels

R. Vanholder, Ghent

D. Verbeelen, Brussels

J. Vienken, Bad Homburg

H.H. Vincent, Nieuwegein

R. Ward, Louisville, Ky.

J.P. Wauters, Bern

V. Wizemann, Giessen

A. Yamashita, Fujisawa

R. Zietse, Rotterdam

T. Zima, Prague 


\section{Aims and Scope}

Practical information on hemodialysis, hemofiltration, peritoneal dialysis and plasma filtration is featured in this journal. Recognizing the critical importance of equipment and procedures, particular emphasis has been placed on reports, drawn from a wide range of fields, describing technical advances and improvements in methodology. Papers reflect the search for cost-effective solutions which increase not only patient survival but also comfort through prevention or correction of undesirable effects. Advances in vascular access and blood anticoagulation, problems associated with exposure of blood to foreign surfaces and acute-care nephrology, including continuous therapies, also receive attention. $\mathrm{Ne}$ phrologists, internists, intensivists and hospital staff involved in dialysis, apheresis and immunoadsorption for acute and chronic solid organ failure will find this journal useful and informative.

\section{Submission}

Manuscripts written in English are considered and should be submitted online at

\section{www.karger.com/bpu}

Should you experience problems with your submission, please contact

$$
\begin{aligned}
& \text { Editorial Office 'Blood Purification' } \\
& \text { S. Karger AG } \\
& \text { PO Box } \\
& \text { CH-4009 Basel (Switzerland) } \\
& \text { Tel. +41 } 613061356 \\
& \text { Fax +41 } 613061434 \\
& \text { E-Mail bpu@karger.ch }
\end{aligned}
$$

\section{Conditions}

All manuscripts are subject to editorial review. Manuscripts are received with the explicit understanding that they are not under simultaneous consideration by any other publication. Submission of an article for publication implies transfer of the copyright from the author to the publisher upon acceptance. Accepted papers become the permanent property of 'Blood $\mathrm{Pu}$ rification' and may not be reproduced by any means, in whole or in part, without the written consent of the publisher. It is the author's responsibility to obtain permission to reproduce illustrations, tables, etc. from other publications.

\section{Conflicts of Interest}

Authors are required to disclose any sponsorship or funding arrangements relating to their research and all authors should disclose any possible conflicts of interest. Conflict of interest statements will be published at the end of the article.

\section{Ethics}

Published research must comply with the guidelines for human studies and animal welfare regulations. Authors should state that subjects have given their informed consent and that the study protocol has been approved by the institute's committee on human research. Further, they should also state that animal experiments conform to institutional standards.

\section{Categories of Manuscripts}

(Word limits include tables, illustrations and references)

- Original Papers are full-length research papers which will be considered for the journal. Articles cover topics relevant to blood cleansing studies (max. 2,500 words).

- In-Depth Reviews are comprehensive, state-of-theart papers (systematic reviews or meta-analyses) on important clinical problems of hemodialysis, hemofiltration, peritoneal dialysis and plasma filtration. In-Depth Reviews may be invited by the Editor or they may be unsolicited (max. 5,000 words), although in the latter, we ask the author to send the Editor a short outline first (300-400 words) to ensure that a review on a similar subject has not already been commissioned. Manuscripts will be assessed in-house and those judged suitable will be peer-reviewed before an editorial decision is made.

- Editorials are usually invited by the Editor (max. 1,000 words). Please send suggestions to the Editor.

- Methods in Blood Purification papers dealing with methodological issues in blood purification studies (e.g. recruitment, exclusion and inclusion criteria, methodological evaluation, novel approaches to clinical trials, statistical analyses and follow-up problems and solutions), particularly with regard to on-going large population-based studies, controlled clinical trials, cohort and case-control studies are welcome (max. 5,000 words).

- Letters to the Editor and Opinions. Manuscripts of max. 500 words, 1 figure or table and max. 10 references are considered for publication provided they describe a novel observation or add pertinent new information.

\section{Arrangement}

Title page: The first page of each paper should indicate the title, the authors' names, the institute where the work was conducted, and a short title for use as running head.

Full address: The exact postal address of the corresponding author complete with postal code must be given at the bottom of the title page. Please also supply phone and fax numbers, as well as e-mail address.

Key words: Please supply 3-10 key words in English that reflect the content of the paper.

Abstract: Each paper needs an abstract in English of not more than 150 words. It should be structured as follows:

Background/Aims: What is the major problem that Methods: prompted the study? Results: $\quad$ Most important findings? Conclusion: Most important conclusion?

Footnotes: Avoid footnotes.

Tables and illustrations: Tables and illustrations (both numbered in Arabic numerals) should be prepared on separate pages. Tables require a heading and figures a legend, also prepared on a separate page. For the reproduction of illustrations, only good drawings and original photographs can be accepted; negatives or photocopies cannot be used. Due to technical rea- sons, figures with a screen background should not be submitted. When possible, group several illustrations in one block for reproduction (max. size $180 \times 223 \mathrm{~mm}$ ) or provide crop marks. Electronically submitted $b / w$ half-tone and color illustrations must have a final resolution of $300 \mathrm{dpi}$ after scaling, line drawings one of $800-1,200$ dpi.

\section{Color illustrations}

Online edition: Color illustrations are reproduced free of charge. In the print version, the illustrations are reproduced in black and white. Please avoid referring to the colors in the text and figure legends.

Print edition: Up to 6 color illustrations per page can be integrated within the text at CHF 800.- per page.

References: In the text identify references by Arabic numerals [in square brackets]. Material submitted for publication but not yet accepted should be noted as 'unpublished data' and not be included in the reference list. The list of references should include only those publications which are cited in the text. Do not alphabetize; number references in the order in which they are first mentioned in the text. The surnames of the authors followed by initials should be given. There should be no punctuation other than a comma to separate the authors. Preferably, please cite all authors. Abbreviate journal names according to the Index Medicus system. Also see International Committee of Medical Journal Editors: Uniform requirements for manuscripts submitted to biomedcal journals (www.icmje.org).

Examples

(a) Papers published in periodicals: Samouilidou E, Grapsa E: Effect of dialysis on plasma total antioxidant capacity and lipid peroxidation products in patients with end-stage renal failure. Blood Purif 2003;21:209-212.

(b) Papers published only with DOI numbers:

Theoharides TC, Boucher W, Spear K: Serum interleukin-6 reflects disease severity and osteoporosis in mastocytosis patients. Int Arch Allergy Immunol DOI: 10.1159/000063858.

(c) Monographs: Tomino Y: IgA Nephropathy. From Molecules to Men, ed 1. Basel, Karger, 1999.

(d) Edited books: Cochrane AL, Ricardo SD: Oxidant stress and regulation of chemokines in the development of renal interstitial fibrosis; in Razzaque MS, Taguchi T (eds): Renal Fibrosis. Contrib Nephrol. Basel, Karger, 2003, vol 139, pp 102-119.

Reference Management Software: Use of EndNote is recommended for easy management and formatting of citations and reference lists.

\section{Digital Object Identifier (DOI)}

S. Karger Publishers supports DOIs as unique identifiers for articles. A DOI number will be printed on the title page of each article. DOIs can be useful in the future for identifying and citing articles published online without volume or issue information. More information can be found at www.doi.org.

\section{Supplementary Material}

Supplementary material is restricted to additional data that are not necessary for the scientific integrity and conclusions of the paper. Please note that all supplementary files will undergo editorial review and should be submitted together with the original

\section{KARGER}

Fax +41 613061234 E-Mail karger@karger.ch www.karger.com 
manuscript. The Editors reserve the right to limit the scope and length of the supplementary material. Supplementary material must meet production quality standards for Web publication without the need for any modification or editing. In general, supplementary files should not exceed $10 \mathrm{MB}$ in size. All figures and tables should have titles and legends and all files should be supplied separately and named clearly. Acceptable files and formats are: Word or PDF files, Excel spreadsheets (only if the data cannot be converted properly to a PDF file), and video files (.mov, .avi, .mpeg)

\section{Author's Choice ${ }^{\mathrm{TM}}$}

Karger's Author's Choice ${ }^{\mathrm{TM}}$ service broadens the reach of your article and gives all users worldwide free and full access for reading, downloading and printing at www.karger.com. The option is available for a onetime fee of CHF 3000.-, which is a permissible cost in grant allocation. More information can be found at www.karger.com/authors_choice.

\section{NIH-Funded Research}

The U.S. National Institutes of Health (NIH) mandates under the NIH Public Access Policy that final, peer-reviewed manuscripts appear in its digital database within 12 months of the official publication date. As a service to authors, Karger submits the final version of your article on your behalf to PubMed Central. For those selecting our premium Author's Choice ${ }^{\mathrm{TM}}$ service, we will send your article immediately upon publishing, accelerating the accessibility of your work without the usual embargo. More details on NIH's Public Access Policy is available at http:// publicaccess.nih.gov/FAQ.htm\#a1

\section{Self-Archiving}

Karger permits authors to archive their pre-prints (i.e. pre-refereeing) or post-prints (i.e. final draft post-refereeing) on their personal or institution's servers, provided the following conditions are met: Articles may not be used for commercial purposes, must be linked to the publisher's version, and must acknowledge the publisher's copyright. Authors selecting Karger's Au- thor's Choice ${ }^{\mathrm{TM}}$ feature, however, are also permitted to archive the final, published version of their article, which includes copyediting and design improvements as well as citation links.

\section{Page Charges}

There are no page charges for papers of 2 printed pages. Each additional complete or partial page will be charged to the author at a rate of CHF 325.00 per page.

\section{Proofs}

Unless indicated otherwise, proofs are sent to the corresponding author and should be returned with the least possible delay. Alterations made in proofs, other than the correction of printer's errors, are charged to the author.

\section{Reprints}

Order forms and a price list are sent with the proofs. Orders submitted after the issue is printed are subject to considerably higher prices.

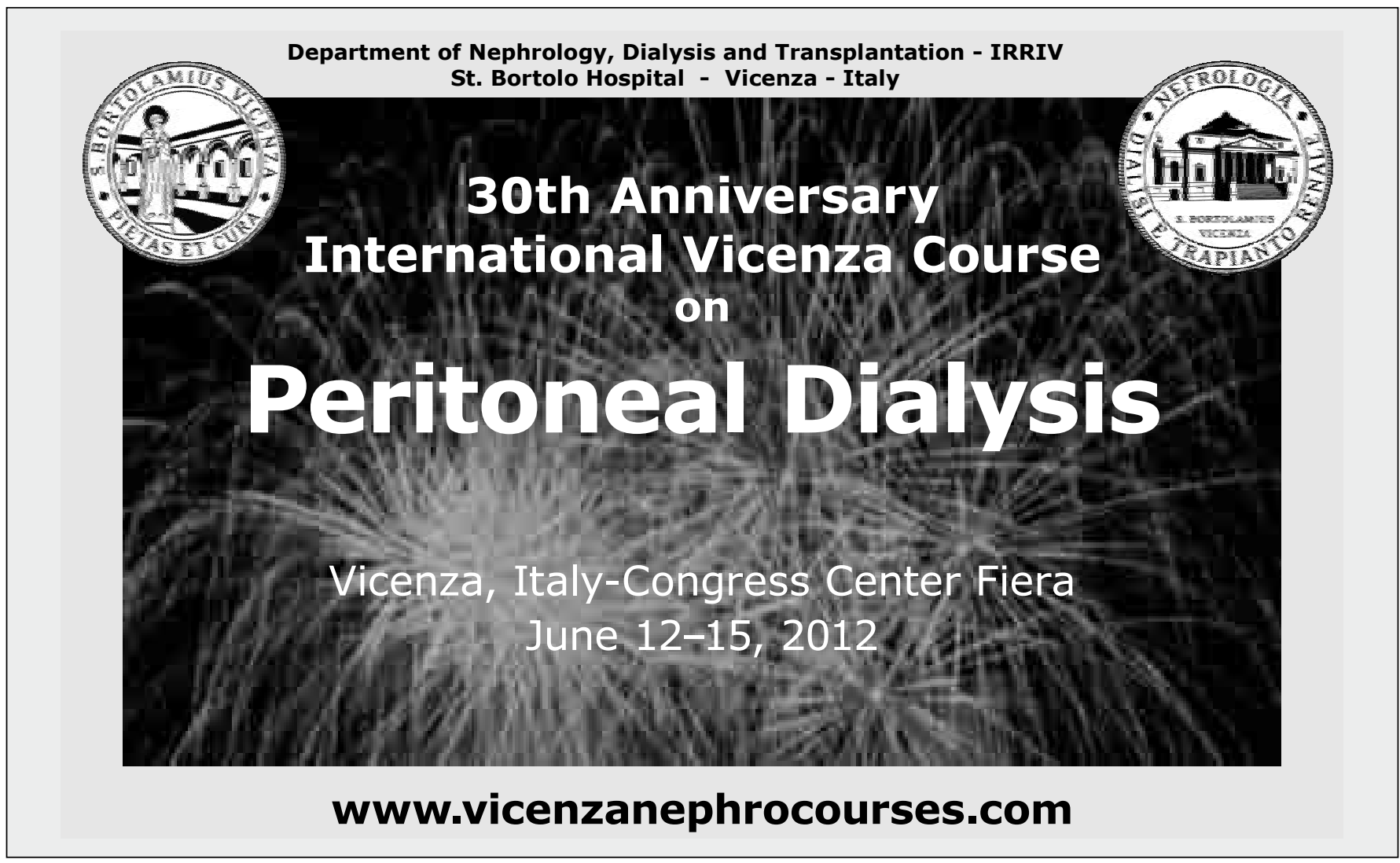

F12231

\section{KARGER}

Fax +41 613061234

E-Mail karger@karger.ch

www.karger.com
(C) 2011 S. Karger AG, Basel

The Guidelines for Authors are available at: www.karger.com/bpu_Guidelines 
ISSN Print Edition: 0253-5068 ISSN Online Edition: 1421-9735

Journal Homepage: www.karger.com/bpu

Publication Data: 'Blood Purification' is published 8 times a year. Volumes 31 and 32, each with 4 issues, appear in 2011

Copyright: (c) 2011 S. Karger AG, Basel (Switzerland). All rights reserved. No part of this publication may be translated into other languages, reproduced or utilized in any form or by any means, electronic or mechanical including photocopying, recording, microcopying, or by any information storage and retrieval system, without permission in writing from the publisher or, in the case of photocopying, direct payment of a specified fee to the Copyright Clearance Center.

Disclaimer: The statements, opinions and data contained in this publication are solely those of the individual authors and contributors and not of the publisher and the editor(s). The appearance of advertisements in the journal is not a warranty, endorsement, or approval of the products or services advertised or of their effectiveness, quality or safety. The publisher and the editor(s) disclaim responsibility for any injury to persons or property resulting from any ideas, methods, instructions or products referred to in the content or advertisements.
Subscription Rates: Subscriptions run for a full calendar year. Prices are given per year. Personal subscription:
Print or Online

CHF 856.20

EUR 634.20

USD 800.40

Print+Onlin

EUR 706.20

USD 890.40

postage and handling (added to print and print+online)

CHF 52.40 Europe, CHF 78.- Overseas

EUR 39.20

USD 72.80

Institutional subscription:

Print or Online

Print+Online combined

CHF 2854.

EUR 2114.-

CHF 3140.-

USD 2668.00

postage and handling (added to print and print+online)

CHF 65.60 Europe, CHF 97.60 Overseas

EUR 48.80

USD 91.20

Airmail surcharge: CHF 66.40 / USD 62.40

Discount subscription prices:

- International Society of Blood Purification(ISBP)

- Japan Society for Blood Purification in

Critical Care (JSBPCC)

- Japanese Society of Hemodiafiltration (JS-HDF)

- Chinese Society of Blood Purification

Administration (CSBPA)
Back Volumes and Single Issues: Information on availability and prices of single print issues and print or electronic back volumes can be obtained from Customer Service at service@karger.ch.

Bibliographic Indices: This journal is regularly listed in bibliographic services, including Current Contents ${ }^{\circledR}$ and PubMed/MEDLINE.

Photocopying: This journal has been registered with the Copyright Clearance Center (CCC), as indicated by the code appearing on the first page of each article. For readers in the US, this code signals consent for copying of articles for personal or internal use, or for the personal or internal use of specific clients, provided that the stated fee is paid per copy directly to

Copyright Clearance Center Inc.

222 Rosewood Drive

Danvers, MA 01923 (USA)

A copy of the first page of the article must accompany payment. Consent does not extend to copying for general distribution, for promotion, for creating new works, or for resale. In these cases, specific written permission must be obtained from the copyright owner,

CH-4009 Basel (Switzerland).
S. Karger AG, P.O. Box

\section{Subscription Orders:}

Orders can be placed at agencies,

bookstores, directly with the Publisher

\section{S. Karger AG}

Medical and Scientific Publishers

P.O. Box

CH-4009 Basel

Switzerland

(for courier services only:

Allschwilerstrasse 10

$\mathrm{CH}-4055$ Basel)

: +416130611 11

f: +41613061234

e: karger@karger.ch

w: www.karger.com or further Karger offices

or representatives:

Germany

S. Karger GmbH

Postfach

79095 Freiburg

Deutschland

(Hausadresse: Wilhelmstrasse 20A

79098 Freiburg)

t: +49761452070

f: +497614520714

e: information@karger.de

w: www.karger.de

Japan

Karger Japan, Inc.

Yushima S Bld. 3F

4-2-3, Yushima, Bunkyo-ku

4-2-3, Yushima,
Tokyo 113-0034

Tokyo

t: +81338151800

f: +81338151802

e: publisher@karger.jp

w: www.karger.jp
Change of Address:

Both old and new address should be sent

to the subscription source.
USA

S. Karger Publishers, Inc.

26 West Avon Road

P.O. Box 529

Unionville, CT 06085

USA

Toll free: +18008285479

t: +18606757834

f: +18606757302

e: karger@snet.net

France

Librairie Médi-Sciences Sar

36, bd de Latour-Maubourg

75007 Paris

France

t: $+33(0) 145514258$

f: $+33(0) 145560780$

e: librairie@medi-sciences.fr

w: www.medi-sciences.fr

Gulf Council Countries, Iran,

Middle East, North Africa, Turkey

Trans Middle East Internationa

Distribution Co. Ltd.

KaSha

Special Free Zone Area

Al Tunaib - Al Sikaah Al Sharq

P.O. Box 827, Code 11621 Khraibet Alsouq

Amman 1162

Jordan

: +96265153467

f: +96265153472

e: info@kasha.cc

w: www.KaShaonline.com
South East Asia, China and Taiwan

CEO Suite Kuala Lumpur

Quill 7, 27th Floor

Jalan Stesen Sentral 5

KL Sentral

Kuala Lumpur 50470

Malaysia

t: +60327766803

f. +60327766999

e: service@karger.cn; r.chew@karger.cn

Karger China

10th Floor, Twin Towers (East)

B12 Jianguomenwai Avenue

Beijing 100022

China

t: +861051235033

f: +861051235122

e: service@karger.cn; r.chew@karger.cn

w: www.karger.cn

India, Bangladesh, Sri Lanka

Medscience India

Plot No. 17, Yusuf Sarai Market

B.L. Glass Building, 2nd Floor

Sri Aurobindo Marg

New Delhi 110016

India

t: +911146029633

f: +911146029634

c: +919891052128

e: medsci.india@gmail.com
Karger Regional Office (Malaysia)

\section{KARGER}

Fax +41 613061234

E-Mail karger@karger.ch

www.karger.com
(C) 2011 S. Karger AG, Basel

The Journal Home Page is available at:

www.karger.com/bpu 


\section{A roadmap for the safe and effective use of therapeutic agents with 1,504 drugs and 2,133 references!}

\section{G. Seyffart}

\section{Seyffart's Directory of}

Drug Dosage

in Kidney

Disease

2011. $X, 870$ pages

1,504 drugs and 2,133 references

ISBN 978-3-87185-400-2

EUR 110.00 / US $\$ 135.00$

+ shipping
Seyffart's Directory of

Drug Dosage in Kidney Disease

The management of patients with renal impairment is a challenge. Such patients frequently have multiple system involvement and require appropriate therapy, but renal impairment affects drug metabolism and makes drug interactions likely

The author, Dr. Günter Seyffart, has had a lifelong interest in this subject and has contributed in very important ways to our current understanding of how drugs can be more safely used in patients with kidney disease. In this directory about 1500 drugs are covered with very specific recommendations (contraindications dosage modifications, and potential nephrotoxicity) concerning use in patients with kidney disease. Such a comprehensive guide, written by an experienced clinical nephrologist, is an invaluable tool for the physician seeking to minimize the risks and optimize the benefits of therapeutic agents in patients with kidney disease of varying severity (as approximated by estimates of the prevailing level of GFR). The systematic approach taken provides not only clarity of exposition but also greatly enhances the practical utility of the Directory. This Directory will help to avoid catastrophes and modulate the risk of adverse events due to drug use in patients with kidney disease. Prevention is an often used byword in medicine - this monograph brings prevention to the bedside.

\section{For further information please visit: www.dustri.com}

Dustri-Verlag Dr. Karl Feistle GmbH \& Co. KG Bajuwarenring 4

82041 Oberhaching, Germany

Fax: +49-89-613 5412

Email: order@dustri.de
Dustri-Verlag Inc.

P.0. Box 561205

Rockledge, FL 32956-1205, USA

Fax: +1-321-414-0219

Email: order@dustri.com

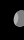

Dustri-Verlag Dr. Karl Feistle 


\section{Contents}

See the journal website for contents

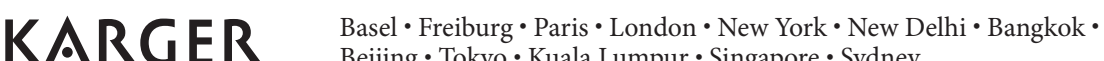
Beijing $\cdot$ Tokyo $\cdot$ Kuala Lumpur $\cdot$ Singapore $\cdot$ Sydney 


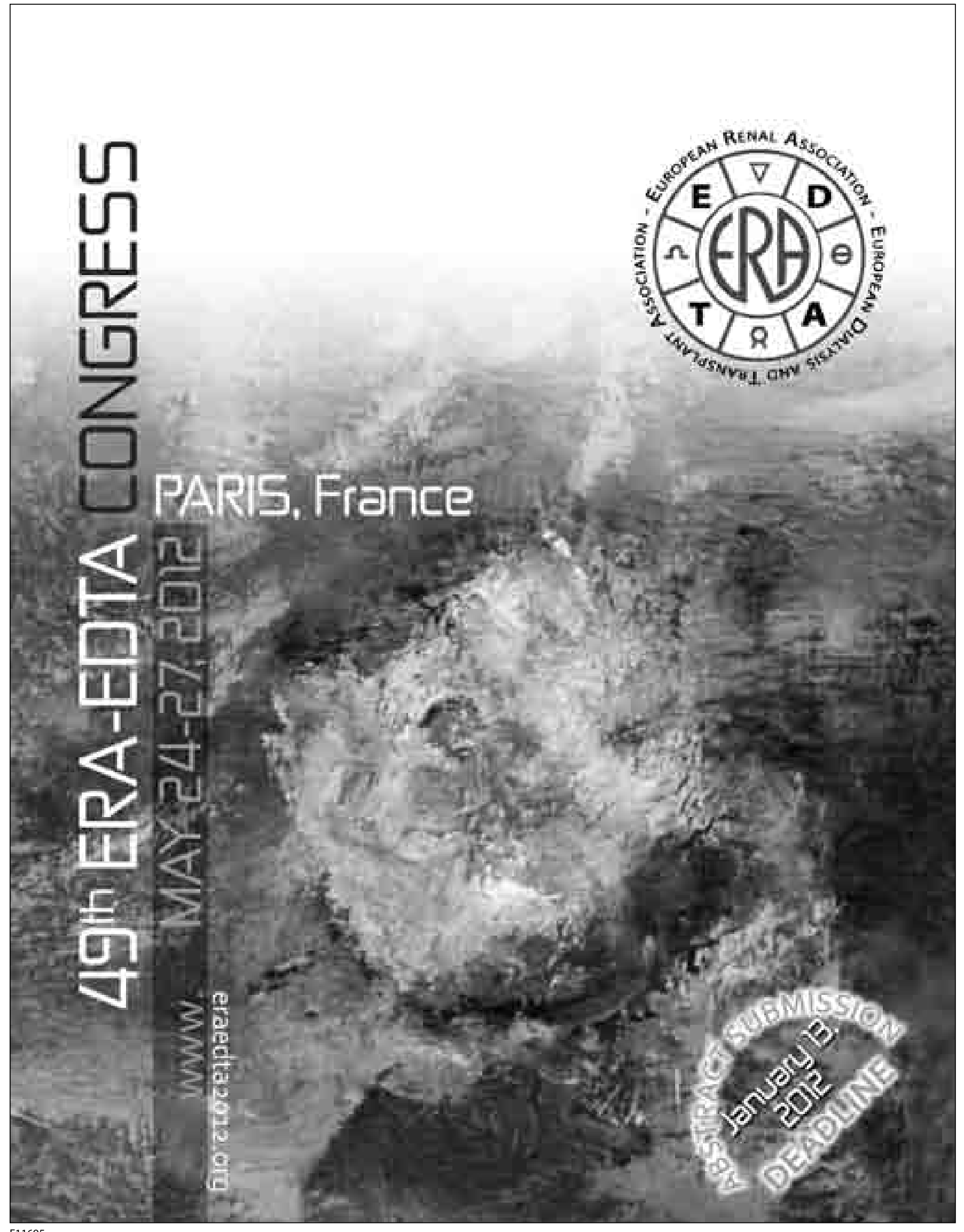



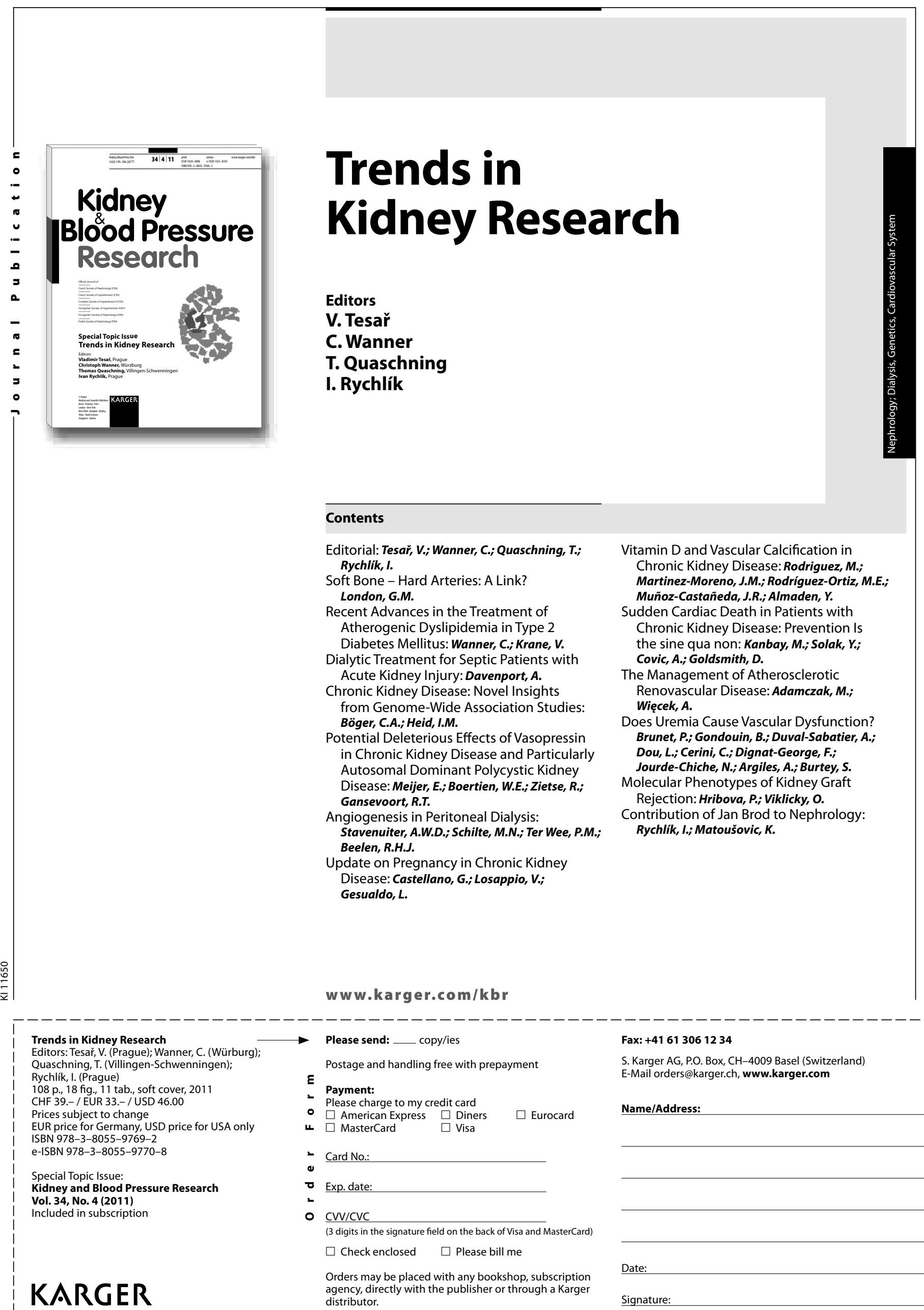

$\rightarrow$ Please send:

Postage and handling free with prepayment

E

Please charge to my credit card

- $\square$ American Express $\square$ Diners $\square$ Eurocard

ᄂ $\square$ MasterCard

$\square$ Master

- Card No.

๑

ర Exp. date:

- CVV/CVC

(3 digits in the signature field on the back of Visa and MasterCard)

$\square$ Check enclosed $\square$ Please bill me

Orders may be placed with any bookshop, subscription agency, directly with the publisher or through a Karger distributor.

Fax: +41613061234

S. Karger AG, P.O. Box, CH-4009 Basel (Switzerland) E-Mail orders@karger.ch, www.karger.com

Name/Address: 


\section{The expert source of research on blood cleansing}

Official Journal of the

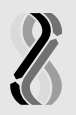

International Society of

Blood Purification (ISBP)

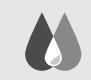

\section{JSBPCC}

Japan Society for Blood Purification in

Critical Care (JSBPCC)

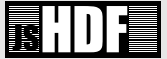

Japanese Society of

Hemodiafiltration (JS-HDF)

\section{Ronco, Vicenza}

Assistant Editor

\section{血液凈化}

\section{Chinese Society of}

Blood Purification Administration (CSBPA)

\section{S. Chiaramonte, Vicenza}
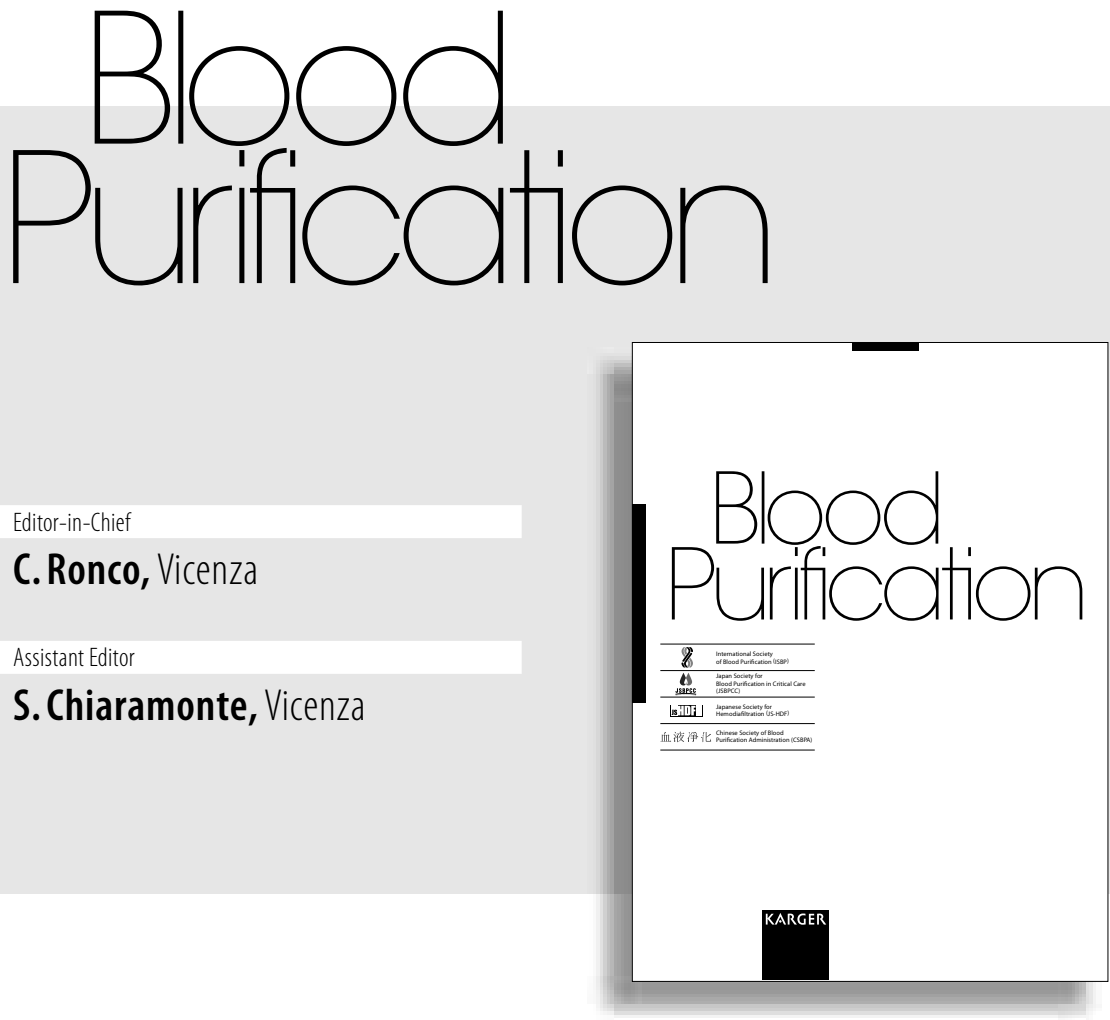

Practical information on hemodialysis, hemofiltration, peritoneal dialysis and plasma filtration is featured in this journal. Recognizing the critical importance of equipment and procedures, particular emphasis has been placed on reports, drawn from a wide range of fields, describing technical advances and improvements in methodology. Papers reflect the search for cost-effective solutions which increase not only patient survival but also comfort through prevention or correction of undesirable effects. Advances in vascular access and blood anticoagulation, problems associated with exposure of blood to foreign surfaces and acute-care nephrology, including continuous therapies, also receive attention. Nephrologists, internists, intensivists and hospital staff involved in dialysis, apheresis and immunoadsorption for acute and chronic solid organ failure will find this journal useful and informative.

\section{Selected contributions}

Insertion Side, Body Position and Circuit Life during Continuous Renal

Replacement Therapy with Femoral Vein Access: Kim, I.B.; Fealy, N.; Baldwin, I.; Bellomo, R. (Melbourne, Vic.)

Modeled Dalbavancin Transmembrane Clearance during Intermittent and Continuous Renal Replacement Therapies: Vilay, A.M. (Albuquerque, N.Mex.I Ann Arbor, Mich.); Shah, K.H. (Bath/Ann Arbor, Mich.); Churchwell, M.D. (Toledo, Ohio/ Ann Arbor, Mich.); Patel, J.H.; DePestel, D.D.; Mueller, B.A. (Ann Arbor, Mich.)

Peritoneal Dialysis in Patients with Primary Cardiac Failure Complicated by Renal Failure: Cnossen, T.T.; Kooman, J.P. (Maastricht); Konings, C.J.A.M. (Eindhoven); Uszko-Lencer, N.H.M.K.; Leunissen, K.M.L.; van der Sande, F.M. (Maastricht)

Principles of Antibacterial Dosing in Continuous Renal Replacement Therapy: Choi, G.; Gomersall, C.D.; Tian, Q.; Joynt, G.M.; Li, A.M.M.Y. (Hong Kong); Lipman, J. (Herston, Qld.)

Uric Acid in Hypertension and Renal Disease: The Chicken or the Egg? Kanbay, M. (Ankara); Solak, Y. (Konya); Dogan, E. (Kahramanmaras); Lanaspa, M.A. (Denver, Colo.); Covic, A. (lasi)

Modern Classification of Acute Kidney Injury: Srisawat, N. (Pittsburgh, Pa.); Hoste, E.E.A. (Pittsburgh, Pa./Ghent); Kellum, J.A. (Pittsburgh, Pa.)

Serum and Urinary Biomarkers of Acute Kidney Injury: Lisowska-Myjak, B. (Warsaw) Fluid Overload in Critically III Patients with Acute Kidney Injury: Cerda, J.

(New York, N.Y.); Sheinfeld, G. (Baltimore, Md.); Ronco, C. (Vicenza)
More information at

\section{www.karger.com/bpu}

- Pay-per-View and Subscriber Access to Full Text

- Full Table of Contents

- Full Editorial Board

- Free Abstracts and Selected Articles

- Online Sample Issue

- Submission/Guidelines for Authors

- Subscription Details

- Free Alert Service

- Online Library Recommendation
Blood Purification

2012: Volumes 33, 34

4 issues per volume

Language: English

ISSN 0253-5068 (print)

ISSN 1421-9735 (online) 


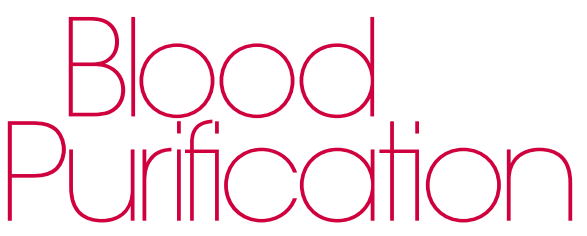

In-Depth Review

262 Septic Acute Kidney Injury: The Culprit Is Inflammatory Apoptosis rather than Ischemic Necrosis

Jacobs, R.; Honore, P.M. (Brussels); Joannes-Boyau, O. (Pessac); Boer, W. (Genk); De Regt, J.; De Waele, E.; Collin, V.; Spapen, H.D. (Brussels)

Original Papers

254 Hypokalemia Is Associated with Increased Mortality Rate in Chronic Hemodialysis Patients

Hwang, J.-C.; Wang, C.-T.; Chen, C.-A. (Tainan); Chen, H.-C. (Kaohsiung)

266 Effects of High Blood Flow and High Pre-Dilution Replacement Fluid Rates on Small Solute Clearances in Hemofiltration

Gashti, C.N.; Rodby, R.A. (Chicago, Ill.); Huang, Z. (Chester, Pa.); Gao, D. (Seattle, Wash.); Zhang, W. (Shanghai)

271 Determination of Dialysis Dose: A Clinical Comparison of Methods

Ahrenholz, P. (Rostock); Taborsky, P. (Prague); Bohling, M. (Wilhelmshaven); Rawer, P. (Wetzlar); Ibrahim, N. (Döbeln); Gajdos, M. (Sokolov); Machek, P. (Most); Sagova, M. (Prague); Gruber, H. (Landshut); Moucka, P. (Kolin); Rychlik, I. (Prague); Leimenstoll, G. (Kiel); Vyskocil, P. (Louny); Toenne, G. (Warendorf); Possnickerova, J. (Chomutov); Woggan, J. (Hamburg-Poppenbuettel); Riegel, W. (Darmstadt); Schneider, H. (Harsewinkel); Wojke, R. (Bad Homburg)

278 Development and Validation of a New Dry Weight Estimation Method Using Single Frequency Bioimpedance in Hemodialysis Patients

Dou, Y.; Cheng, X.; Liu, L.; Bai, X.; Wu, L.; Guo, W.; Zhao, X.; Wang, F.; Cao, L.; Zuo, L. (Beijing)

286 Adsorptive Modulation of Inflammatory Mediators Dampens Endothelial Cell Activation

Schildberger, A.; Buchacher, T.; Weber, V.; Falkenhagen, D. (Krems)

296 Increased Calcification and Protein Nitration in Arteries of Chronic Kidney Disease Patients

Guilgen, G.; Werneck, M.L.; de Noronha, L.; Martins, A.P.C.; Varela, A.M.; Nakao, L.S.; Pecoits-Filho, R. (Curitiba)
303 A New Endotoxin Adsorber in Septic Shock: Observational Case Series

Ala-Kokko, T.I.; Laurila, J.; Koskenkari, J. (Oulu)

310 Reduction in Serum High Mobility Group Box-1 Level by Polymyxin B-Immobilized Fiber Column in Patients with Idiopathic Pulmonary Fibrosis with Acute Exacerbation Abe, S.; Hayashi, H.; Seo, Y.; Matsuda, K.; Kamio, K.; Saito, Y.; Usuki, J.; Azuma, A.; Kudo, S.; Gemma, A. (Tokyo)

317 Effectiveness of $\boldsymbol{\beta}_{2}$-Microglobulin Adsorption Column in Treating Dialysis-Related Amyloidosis: A Multicenter Study

Kuragano, T. (Nishinomiya); Inoue, T. (Takatsuki); Yoh, K. (Nishinomiya); Shin, J.; Fujita, Y.; Yoshiya, K. (Kobe); Kim, J.I. (Osaka); Sakai, R. (Kobe); Sekita, K. (Miki); Goto, T. (Takasago); Fukagawa, M. (Kobe); Nakanishi, T. (Nishinomiya)

323 Delivering Quality of Care while Managing the Interests of All Stakeholders

Stopper, A.; Raddatz, A.; Grassmann, A.; Stuard, S.; Menzer, M.; Possnien, G.; Scatizzi, L.; Marcelli, D. (Bad Homburg)

331 Cost-Effectiveness Analysis of Polymyxin-B Immobilized Fiber Column and Conventional Medical Therapy in the Management of Abdominal Septic Shock in Italy Berto, P. (Verona); Ronco, C.; Cruz, D. (Vicenza); Melotti, R.M. (Bologna); Antonelli, M. (Rome)

Case Report

249 Successful Salvage of Peritoneal Catheter in Unresolved Methicillin-Resistant Staphylococcus aureus Peritonitis by Combination Treatment with Daptomycin and Rifampin

Lin, S.-Y.; Ho, M.-W.; Liu, J.-H.; Liu, Y.-L.; Yeh, H.-C.; Hsieh, T.-L.; Wang, I.-K.; Lin, H.-H.; Huang, C.-C. (Taichung)

Letter to the Editor

253 The Arteriovenous Fistula: Lesser Evil or God's Blessing? Basile, C.; Lomonte, C. (Acquaviva delle Fonti); Konner, K. (Cologne)

341 Acknowledgement to Reviewers after 342 Contents Vol. 32, 2011 